\title{
Study on Balance and Improvement of College English Class in China
}

\author{
Junhong Tang, Jiancheng Wang \\ Foreign Language Department, Baoding University, Baoding, China \\ Email: jessytang99@163.com
}

Received 3 July 2014; revised 20 August 2014; accepted 4 September 2014

Copyright (C 2014 by authors and Scientific Research Publishing Inc.

This work is licensed under the Creative Commons Attribution International License (CC BY). http://creativecommons.org/licenses/by/4.0/

c) (i) Open Access

\begin{abstract}
Considering the current problems in English class, "5C" strategies, cooperation, competition, consideration, creativeness and continuity are used to balance and improve the English class in China on the basis of some fundamentals like "Symbiotic Effect", "Niche", "Zone of the Optimum" and "Flowerpots Effect". Meanwhile, it is also very important and urgent to offer opportunities of further study for English teachers in order to balance and improve the English class according to "Edge Effect".
\end{abstract}

Keywords

Balance, Optimize, Teachers, Students, 5C Strategies

\section{Introduction}

Nowadays, not many English teachers get chances to go abroad for further study or get the mid-career studies, which cause many English teachers owning a bucket of "dead" water and their knowledge and teaching method cannot update and replenish efficiently. Moreover, the English teaching evaluation methods lack variety and the rewards and punishment system is not clear. So many English teachers teach for exams and many students study for the exams, too. So many English teachers in China still follow the "jug-and-mug" teaching method. In the "jug-and-mug" teaching, the students get used to taking notes, doing exercises and checking answers. They are not willing to open their mouths to express their thoughts. Thus the students lack the learning passion and motivation [1]. In order to solve such problems, the researcher states some ideas on the basis of educational ecology.

Educational Ecology, which is based on such fundamentals of ecology as ecological system, ecological balance and co-evolution, studies various educational phenomena and the causes of them, then grasps the rules of educational development and reveals the development trend and direction of education [2]. The basic principles of educational ecology offer theoretical guidance for education policy and practice, especially the education 
reform. Meanwhile, they also infuse new vitality into English teaching reform and innovation.

In order to balance and improve college English class, the article puts forward such strategies as ensuring the balance of the class scale, ensuring balanced discourse power between the teacher and students, ensuring balanced discourse power between the students and making ecological teaching target to avoid "Flowerpots Effect". Then using "Edge Effect" resourcefully and ensuring the teachers have "dynamic water" is put forward. At last, the significance of balance and improvement of class ecology is discussed.

\section{Strategies for English Class Balance and Improvement}

In order to maintain the balance and optimization of the English class, the class scale, the discourse power between the teacher and the students, and the discourse power among the students must be noticed. Meanwhile, the teachers are supposed to try their best to avoid "Flowerpots Effect" during the teaching process.

\subsection{Ensure the Balance of the Class Scale}

According to the ecology principles, it is constant for resources affordability and the total of the environmental accommodation in a certain time. The unsuitable density will have a bad effect on the students. The most proper number of the students in a class is about 30 in terms of the teaching efficiency. Unfortunately, there are 60 or even 70 students in some English class. More students there are, fewer opportunities there are for the students to practice English. Day by day, the students' English learning motivation will shrink. This phenomenon requires the reasonable configuration in terms of the teachers and other teaching resources.

\subsection{Ensure Balanced Discourse Power between the Teacher and Students}

The current English teaching follows the "jug-and-mug" teaching method which regards the students as a container and ignored the students' active cognitive engagement. There is no real sense of communication and it is difficult to stimulate the learners' intrinsic motivation [3].

In order to know the students' English learning situation and get the balance and optimization of the class ecology, the researcher made a simple descriptive statistics expressed as percentages [4], which is listed in Table 1.

Table 1. Descriptive statistics.

\begin{tabular}{|c|c|c|}
\hline Questions & Choices & Percentage \\
\hline \multirow{4}{*}{ Q4: Do you like the “jug-and-mug” teaching method? } & 1 = like it very much. & 0.65 \\
\hline & 2 = I wish I liked It & 3.27 \\
\hline & $3=$ do not like it very much. & 10.56 \\
\hline & $4=$ do not like it at all & 85.82 \\
\hline \multirow{4}{*}{ Q5: Do you think English Speech Contest can stimulate your E } & $1=\mathrm{I}$ think so. & 75.58 \\
\hline & 2 = I don't think so. & 8.24 \\
\hline & 3 = Maybe. & 16.15 \\
\hline & 4 = I don’t know & 0.03 \\
\hline \multirow{4}{*}{ Q6: Do you agree the English speech contest can improve your } & 1 = agree very much & 67.69 \\
\hline & 2 = agree a little & 7.54 \\
\hline & $3=$ agree & 21.87 \\
\hline & $4=$ do not agree at all & 2.90 \\
\hline \multirow{4}{*}{$\begin{array}{l}\text { Q7: Do you hope your teacher will ask you questions that can } \\
\text { make you more confident during the English class? }\end{array}$} & 1 = I hope very much. & 65.35 \\
\hline & 2 = I hope a little & 5.65 \\
\hline & 3 = I hope. & 25.83 \\
\hline & 4 = I don't hope. & 3.17 \\
\hline
\end{tabular}


In Question 4, do you like the "jug-and-mug" teaching method, 85.82\% students do not like it at all and only $0.65 \%$ students like it very much. This shows most of the students do not like the "jug-and-mug" teaching method. In Question 5, do you think English Speech Contest can stimulate your English learning interest, 75.58\% students chose "I think so". And in Question 6, 67.69\% students agree that the English Speech Contest can improve their English level.

According to the basic principles of ecology, individuals that are in the same Niche will compete with each other, which will enhance their individual adaptation. Meanwhile, the "Symbiotic Effect" shows that the mutual communication and influence will promote the whole group ascension greatly [5]. Considering this, the teacher can organize students make drama performance, speech, debate, etc. Through COOPERATION and COMPETITION between the students, the learning motivation will be stimulated.

In Question 7, do you hope your teacher will ask you questions that can make you more confident during the English class. 65.35\% students chose "I hope very much" and 25.83\% students chose "I hope", while only 3.17\% students chose "I don't hope”. This reveals 91.18\% students welcome suitable questions for their own English level. So this requires the teacher must and have to pay attention to the individual differences of the students, treat each student differently and show enough CONSIDERATION and CREATIVENESS during the class.

"The Law of Tolerance" and "the Most Appropriate Principle" shows each ecological factor has its own upper and lower adaptable limits. During the limit, the factor can develop very well; otherwise it will go reverse [6]. Considering this, the teachers are expected to insist on CONSIDERATION and CREATIVENESS during their teaching to make sure each student can find the most suitable learning environment and make each student get maximum development.

In order to realize CONSIDERATION and CREATIVENESS, the teachers should try their best to grasp each student's information as much as possible. For example, students' English learning attitude and motivation, the English entrance score, family background, characteristics. On the basis of the comprehensive understanding of each student, the teacher is able to treat each student differently in class question, discussion, assessment. As to the students whose English level is not well, the teacher should encourage them and stimulate their confidence and interest in English. For example, the teacher had better ask some simple questions like reading new words or answer some simple questions, by which to help the students to build up their confidence in English learning. As to the students whose English level is ok, the teacher can inspire them and crave out their competitive consciousness. During the class, some more difficult questions like analyzing some long difficult sentences can be offered to them. As to the students whose English level is well, the teacher are supposed to exhort them to make them work harder.

By using such teaching strategies as cooperation, competition, consideration and creativeness, the teacher is supposed to cultivate students' ecological learning strategy which enable students learn by themselves in the future and realize their continuous learning.

\subsection{Ensure Balanced Discourse Power among Students}

The position of the teacher in the classroom will affect the students' psychology and the teaching effect. The students around the teacher will act actively while the students are comparatively far away from the teacher are passive. The teacher is more likely to sit or stand near the computer in order to control the computer easily in the multi-media classroom, so the students who sit in the rear or side line are in the adverse ecological niche and they are easily ignored. So the teacher should organize the students change their seats regularly to make sure each student in the active area and gain equal discourse power.

\subsection{Making Ecological Class Teaching Target to Avoid "Flowerpots Effect"}

Since the shortcomings of Chinese exam rules and the system of teacher assessment, some teachers teach only for the exams and some students study for the exam too. During the English teaching, some teachers focus on CET-4 (College English Test Band Four) and CET6 (College English Test Band Six) and other types of exams. In this way, the students indeed can gain a good score and thus the students also think their teacher is a good teacher, while this teaching method completely neglects cultivating the students' ecological learning strategies and hinders the students' overall progress and all-around development in terms of adaptability and long-term development [7].

We must avoid this "Flowerpots Effect", which means the individual will grow well and healthily in its small regular ecological environment, but it is very hard for the individual to adjust to a new environment. So we must 
make ecological teaching target for each class which requires us not to teach only for exams which requires the teachers not only to teach words, grammar and sentences but to help students obtain self-learning ability and skills and students' autonomous ability which can contribute to the life education and sustainable development. In order to meet that CONTINUITY, the English teachers should not only put emphasis on the textbook but actively organize such activities as Foreign Language Salon, English Corner, and English Speech Contest to improve the students' self-learning ability.

\section{Use the "Edge Effect" Resourcefully and Ensure the Teacher Have "Dynamic Water"}

If the English class is the battle field, the teacher is the commander and the students are the soldiers on the battle field. The win of a battle depends largely on the ability of the commanding officer. So facing the fast-changing battle field and the opponents, the commander must improve and perfect his or her strategies. So the researcher made a simple investigation into the current English teachers' further study, which is shown in Table 2.

Nowadays, "students-centered" teaching method is emphasized. The teacher's role in the class is not be weakened, but be strengthened. The teacher is supposed to be the organizer, the guide and the supervisor.

However, the statistics in Q8, Mean = 1.12, Median = 1.35, Mode =1, shows that few English teachers got the chance to go abroad for further study. And a few teachers are so lucky that they can go to another institute for further study which can be seen in Q9, Mean $=1.89$, Median $=1.97$, Mode $=2$. In contrast, most English teachers would like to go abroad or go another institute for their further study which is shown in Q10, Mean = 1.15 , Median $=1.22$, Mode $=1$.

Just as the saying goes: "If we want to give the students a bowl of water, we must have a bucket of water." No matter how big the bucket is, it is really a bucket of immobile water. It is dead water. Moreover, this bucket of water will evaporate day by day. So, in order to be a good teacher, the teacher must have "dynamic water". Because it is dynamic, it will not dry out. Because it is mobile, it will not lack of nutrition.

In order to gain "dynamic water", the English teacher can continue their further study or learn some other knowledge in such fields as education, psychology and philosophy to broaden their mind. Moreover, the trend of the integration of science and technology and interdisciplinary is strengthening, so we should make full use of the "Edge Effect" which means getting the perfect effect through exchanging talents and learning different knowledge from different subject. As an English teacher, he need to study in a higher institution at home or abroad, accept new idea of teaching, take the ideas into his own teaching process and improve the efficiency of English teaching.

Table 2. Investigation on the current English teachers' further study.

\begin{tabular}{|c|c|c|c|c|c|}
\hline Questions & Choices & Number & Mean & Median & Mode \\
\hline \multirow{4}{*}{ Q 8: Do you usually go abroad for further study? } & $1=$ Never & & & & \\
\hline & 2 = Seldom & 150 & 1.12 & 1.35 & 1 \\
\hline & $3=$ Sometimes & & & & \\
\hline & 4 = Often & & & & \\
\hline \multirow{4}{*}{ Q 9: Do you usually go to another institute for further study? } & $1=$ Never & & & & \\
\hline & 2 = Seldom & 150 & 1.89 & 1.97 & 2 \\
\hline & $3=$ Sometimes & & & & \\
\hline & $4=$ Often & & & & \\
\hline \multirow{4}{*}{ Q 10: Would you like to go abroad or go another institute for further study? } & 1 = I like it very much. & & & & \\
\hline & 2 = I like it. & & & & \\
\hline & 3 = Maybe I like it & & & & \\
\hline & 4 = I don't like it. & 150 & 1.15 & 1.22 & 1 \\
\hline
\end{tabular}




\section{The Significance of the Balance and Improvement of Class Ecology}

Making full use of the "Edge Effect will ensure the teacher have the "dynamic water", which can improve the English teaching efficiency efficiently because the teacher's moral quality, political quality and psychological quality will be enhanced, which enable the teacher make ecological class teaching target and avoid the "Flowerpots Effect" by use of "Symbiotic Effect" and "Niche" and make each student in the Zone of the Optimum. Only in this way can we stimulate the students' learning enthusiasm and improve the teaching efficiency and ensure the sustainable development of the English teaching.

\section{Acknowledgements}

The paper is under the project of A Study on Ecological English Teaching (133111) and A Study on the Balance and Improvement of the Chinese College English Class Ecology (2013J04). All the project members made their contributions to the paper. The researcher also thanks all my friends and classmates who live in different cities, which made my paper more persuasive.

\section{References}

[1] Wei, Y.H. (2004) A Study on Task-Based Teaching Method. Huadong Normal University Press, Shanghai.

[2] Fan, G.R. (2000) Educational Ecology. People’s Education Press, Beijing.

[3] Li, S. (2011) Ecological Class—Harmony and Creation. People’s Education Press, Beijing.

[4] Pei, D.N. (2009) An Introduction to Methods for Education and Research. Anhui Education Press, Hefei, 60-70.

[5] Wu, D.F. (2000) Educational Ecology. Jiangsu Education Press, Nanjing.

[6] Lei, Y. (2001) A Study on Deeper Ecology. Peking University Press, Beijing.

[7] Yang, X.Y. (2003) Class Teaching Strategies of Foreign Teachers, Foreign Language Teaching and Study. http://www.docin.com/p-336434287.html 
Scientific Research Publishing (SCIRP) is one of the largest Open Access journal publishers. It is currently publishing more than 200 open access, online, peer-reviewed journals covering a wide range of academic disciplines. SCIRP serves the worldwide academic communities and contributes to the progress and application of science with its publication.

Other selected journals from SCIRP are listed as below. Submit your manuscript to us via either submit@scirp.org or Online Submission Portal.
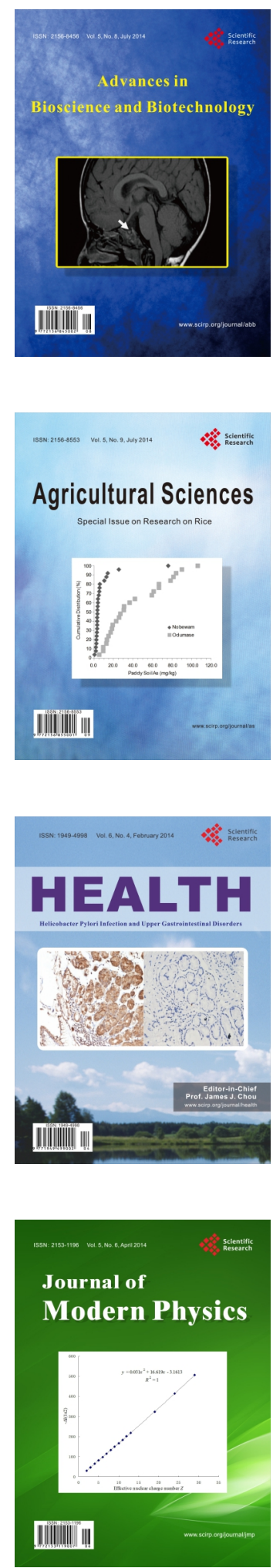
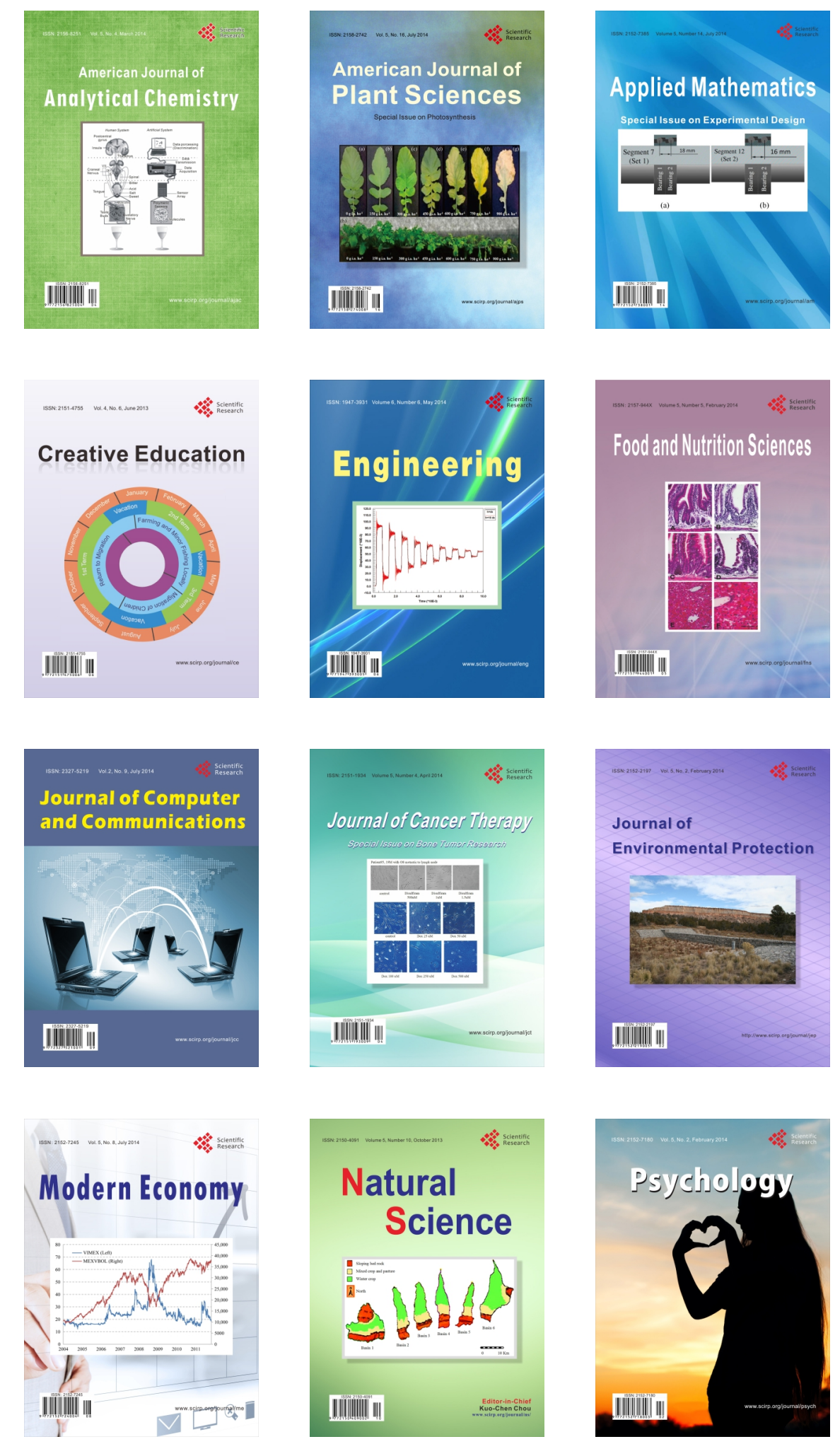